\author{
Aleksandar Popovic \\ Univer $\mathrm{GmbH}$ \\ 65428 Rüsselsheim \\ Germany \\ Bozica Bojovic \\ Assistant Professo \\ Production Engineering Department \\ Faculty of Mechanical Engineering \\ University of Belgrade \\ Serbia \\ Marcel Suter \\ Optotune Consumer Switzerland AG \\ $\mathrm{CH}-8953$ Dietikon \\ Switzerland \\ David Niederer \\ Optotune Switzerland AG \\ $\mathrm{CH}-8953$ Dietikon \\ Switzerland
}

\section{Design Parameters Effect to Magnetic Flux Distribution of the Reluctance Actuator}

The paper presents an analysis of reluctance actuator for speckle reducing in laser based projectors, head-up displays, metrology and 3D scanning units to improve the quality of the generated images by a moving diffuser. Design concepts for one-dimensional laser speckle reducer actuator are analyzed through different designs structures. There are two resonant structures with three spring lengths, and two actuation structures with single tooth and double teeth. Reluctance actuator is evaluated in details, taking into account simple design and functional requirements of the laser speckle reducer (generated force and maximum displacement). The resonate frequency and influence of geometrical parameters are determined with the use of COMSOL Multiphysics. The forces developed through the actuating structures are obtained from the simulated material magnetic flux distribution, saturation. Evaluation suggests the next steps in the actuating structure optimization from which better performance of the device could be obtained.

Keywords: Laser, Speckle, Magnetic flux, Optimization, Reluctance force

\section{INTRODUCTION}

A very important property of the laser is a high degree of coherence that enables interference processes, which leads to a significant drawback for application that uses a light detector. This effect reduces the resolution of measurement systems but also causes noise in projected images known as speckle pattern, which is detailed in [1]. In short, speckle appears when a coherent light scattered from a rough surface is detected by an observer's eye. Angle, polarization, and wavelength of the illuminating laser beam are three light parameters on which the speckle essentially depends, as is stated in [2]. A good example of implemented angle diversity reduction by employing a time-varying diffuser is developed by Optotune's laser speckle reducer (LSR) $[1,3,4]$ as a moving diffuser. LSR is a good choice for application in: laser projection displays, head-up displays, beam homogenizer, metrology, microscopy, interferometry and lithography. Electro-active polymers (EAP) based LSR are ultra-compact and minimal weighted, without noise and vibrations, that is explained in $[1,3]$. Therefore, EAP LSR is particularly attractive for hand-held devices. The reluctance force based LSR, which is presented in [4], is suitable for applications that require large format glass diffusers, high diffuser displacement, lower voltage and higher temperature. The basis of this type LSR is single thin steel structure that is brought into resonance by the pulsing actuating coil, which generates a strong reluctance force.

This paper presents an analysis of a reluctance actuator (RA) for Optotune's LSR, which is the result of

Received: Mach 2020, Accepted: May 2020

Correspondence to: Dr Bozica Bojovic

Faculty of Mechanical Engineering,

Kraljice Marije 16, 11120 Belgrade 35, Serbia

E-mail: bbojovic@mas.bg.ac.rs

doi: $10.5937 /$ fme2003504P

(C) Faculty of Mechanical Engineering, Belgrade. All rights reserved student's traineeship (Mentor and main lead at the University was Prof. Bozica Bojovic and at Optotune Dr. Marcel Suter). Although our reluctance actuator work was done in 2012, this is a contemporary topic as the hybrid case which is applied for high precision motion in $[5,6]$.

Taking into account simple design and functional requirements of the LSR, like the generated force and maximum displacement, RA is evaluated and analysed with the use of software COMSOL Multiphysics. The resonate frequency and influence of geometrical parameters are determined for a diffuser moving in one plane. Magnetic flux distribution and saturation of material is observed with the help of FEM simulations. The forces developed through the actuating structures are obtained from the analysed magnetic flux distribution. The FEM simulation approach is suitable for reluctance actuator characterization and practicality of it is evidenced in [7].

The presented analysis represents a good guideline for further LSR development and optimization process of the new actuation technique. It provides a better understanding of the working principle and points out where more attention in the evaluation is needed.

\section{MATERIALS AND METHODS}

Reluctance actuator is an electromagnetic actuator where force is produced by the tendency of its movable part to move towards a position where the inductance of the excited winding is maximized [8]. The force generation in RA is explained using the elementary principle of electromechanical energy conversion in a solenoid. The solenoid excited by current, will generate the flux at the coil. To maintain the same magnetic flux, greater current should flow in the winding and consequently greater energy is stored in the magnetic circuit. With the increase of the current, the translator 
will move towards the stator, decreasing distance between them. If the inductance linearly varies with the translator position for a given current, the magnetic force acting on the translator can be derived as presented below:

$$
F_{m}=\frac{1}{2} \mu_{0} A \frac{I^{2} N^{2}}{d^{2}}
$$

where $\mu_{0}$ is the vacuum permeability, $A$ the area of the pole face, $I$ the current in the coil, $N$ the winding numbers of the coil and $d$ the length of the air gap, according to [4]. The force $F m$ is pulling the translator towards the stator decreasing the air gap.

Diffuser movement of the LSR can be described as a damped harmonic oscillation with external excitation. Such movement of the diffuser has its maximum amplitude at the in-plane resonant frequency of the system. Damping can often be described by the quality factor Q, which is a ratio between the total system energy and the average energy loss in one radian at resonant frequency. A higher factor $\mathrm{Q}$ implies a narrow resonance peak of the oscillator, which is shown in $[9,10]$. RA has a nonlinear force-displacement curve, which is shown in Figure 1.

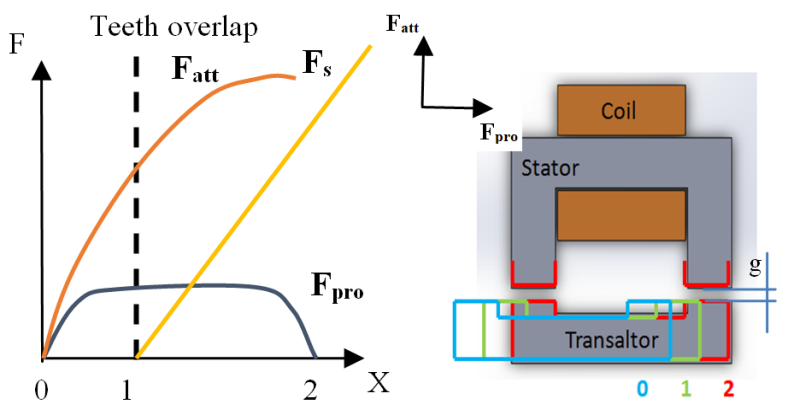

Figure 1. RA magnetic force interaction with linear spring, LSR. Magnetic force $F_{\text {att }}$ and $F_{\text {pro, }}$, spring force $F_{\mathrm{s}}$. Teeth overlap length depends of design and it is $0.2 \mathrm{~mm}$ and $0.1 \mathrm{~mm}$ respectively

The flux density $B g$ in the air gap $g$ is given by:

$$
B_{g}=\frac{\Phi}{X Y}
$$

According to (2), the propulsion force $\mathrm{F}_{\text {pro }}$ and attraction force $\mathrm{F}_{\text {att }}$ are given in (3) and (4), where $\mathrm{X}, \mathrm{Y}, \mathrm{Z}$ are the overlapped lengths on the related position of the translator, stator and $\Phi$ the magnetic flux.

$$
\begin{aligned}
& F_{\text {pro }}=\frac{B_{g}{ }^{2}}{2 \mu_{0}} \cdot Y Z \\
& F_{\text {att }}=\frac{B_{g}{ }^{2}}{2 \mu_{0}} \cdot X Y
\end{aligned}
$$

Due to the nonlinear characteristics of the force, it is hard to modify the force along displacement, especially in the range of a small air gap. Therefore, FEM is used to modify force-displacement curve in [11]. In order to fit the requirements of the LSR application, we benefit from FEM analysis, which gives a good chance to modify the force by simply changing the geometry of the translator and stator allowing different characteristics [11]. The goal of the simulations to determine the flux distribution and occurred forces, from which interaction with the spring force can be compared. Spring steel was considered due to good elastic properties and low damping. Although it is a good example for resonating structures, unfortunately in terms of magnetic properties the spring steel is weak compared to some magnetic material. Despite the drawback, the spring steel is used for the LSR design evaluation.

The nonlinear material properties have been assigned to the LSR structure, including H(B) curves for the magnetic field calculation. All other domains have been assigned as air with the permeability $\mu_{0}$. The coil was represented like a rectangle $7 \times 7.75 \mathrm{~mm}$, the material is copper and the excitation is given by the calculated coil current density. The method used for the force calculation is Maxwell Stress Tensor as COMSOL default method for magnetic force calculation. It is mathematically an integral across a closed path (2D) or closed surface area (3D) around a domain of interest. In the case of the LSR the domain of interest is the moving part (translator). Simulation parameters are:

Material:

- Surrounding = Air

- 1 D structure analysis $=$ Spring steel

- Coil = Cooper

Magnetic field:

- Second Amperes law settings =Material type: solid, Magnetic field - constitutive relation: HB curve

- Coil excitation = External current density: $\mathrm{Jc}=11 \cdot 10^{6}\left[\mathrm{~A} / \mathrm{m}^{2}\right]$.

- Force calculation $=$ the moving part (translator) domain is selected

Mesh Size $=$ extremely fine

Study

- Stationary

- Swiped parameter is the translator position related to the stator.

- 1D structure analysis parametric sweep setup = range: start $-0.5[\mathrm{~mm}]$, step $0.1[\mathrm{~mm}]$, end $1.4[\mathrm{~mm}]$ for the single tooth design. For the double teeth design the range is: start -0.2 [mm], step $0.1[\mathrm{~mm}]$, end $0.5[\mathrm{~mm}]$.

FEM analysis of the magnetic properties results in flux distribution and force generated from the actuator. Two different resonant structures with three spring lengths and two actuation structures (single tooth and double teeth) were made to analyse and determine the parameters that influence the resonant modes.

\section{LASER SPECLE REDUCERS ANALYSIS}

One dimensional LSR design was divided into resonant structure and actuator structure evaluation. This LSR implements one dimensional diffuser movement, which is shown in Figure2. Three different resonant and two actuating structures are suggested using FEM analysis for the actuator in Master thesis [12]. The structure is made out of a single sheet metal, in the considered spring steel. The stator, translator and coil form together the actuating structure, where the translator is actually 
the diffuser carrying frame. Figure 2 shows the one dimensional LSR with the corresponding resonant and actuating structure.

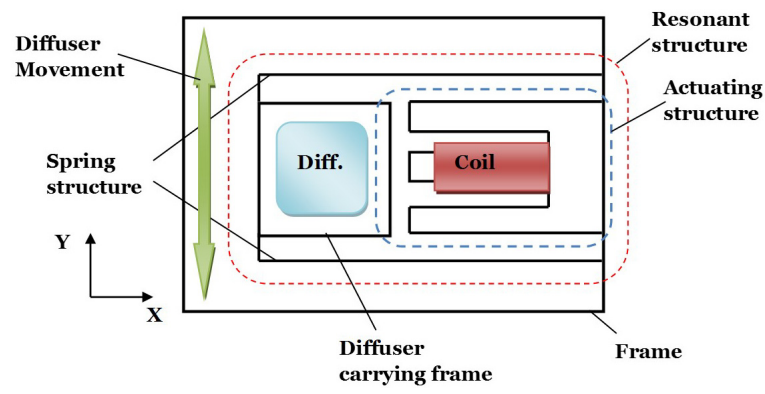

Figure 2. LSR with mechanical resonant structure and actuating structure

In the resonant structure evaluation process, the spring lengths and spring ratios were determined regarding the resonant modes that occur. Several design approaches were made to analyse and determine the parameters that influence the resonant modes. Afterwards, when the best possible solution was made, regarding the requirements, it was carried on with the final design, which was further developed for the best performance. The versions were made regarding the resonant frequencies. The actuator geometry and layout is evaluated regarding the force demands. Same, the relation between the stator and translator were determined as well. The relation is in terms of the air gap length and overlap between the poles.

The input parameters for the coil parameter calculator are made regarding the limited max current and voltage, and the limited space for the coil. For more details see [9], since the coil design approach is not this paper's focus. It is worth mentioning that the generated magnetic field is not only dependent on the applied current, it is as well influenced by the coil geometry and by the current density. The larger current density can contribute to the high magnetic field but can result in coil overheating.

\subsection{Resonance Structure Design}

In this paper two designs are presented where the connection point of the frame and the spring length is varied. Figure 3 shows the resonance structure design suggestions. The connection of the spring and diffuser carrying frame is: a) on the left corner, where the springs are longer (Design 1); b) on the right corner, where the springs are shorter (Design 2). The approach to divide the resonant modes is to vary the spring ratio, which is illustrated in Figure 3.
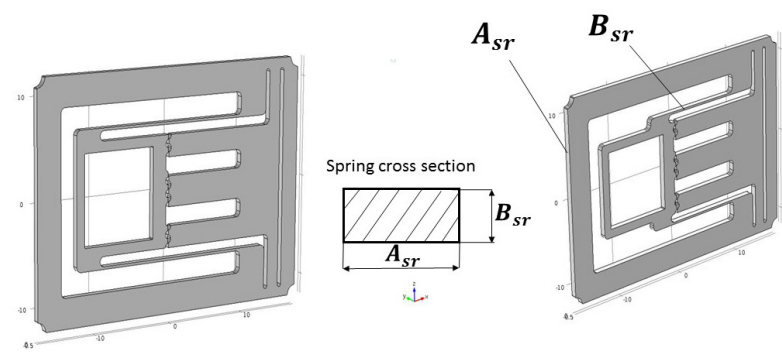

Figure 3. Resonance structure Design 1 (left) and Design 2 (right) with spring ratio Asr $\times$ Bsr
By varying the spring ratio, it is meant on changing the cross section of the spring beam. Simply changing the thickness of the structure, Asr (width of the spring beam) or Bsr (height of the spring beam), the resonant frequency is changed in different direction.

The resonant frequency in different direction can be approximated with the use of Rayleigh-Ritz method, where the spring beam is considered as a beam with end mass, which is elaborated in [9]. In the resonant structure evaluation process, the spring lengths and spring ratios were analysed regarding the resonant modes that occur. Aim of resonance structure design is to achieve resonant diffuser movement only along one axis. Resonant movement of the diffuser is mandatory to stay inplane, an out-of-plane movement is not desired. The planned resonant frequency should be $>60[\mathrm{~Hz}]$, the desired $>100[\mathrm{~Hz}]$. Amplitude peak of the resonant movement should be $>0.5[\mathrm{~mm}]$. The main problem of the resonance structure are the different resonant modes that could occur since every system has its own natural frequency. The design challenge is to find and overcome the resonant modes by dividing the desired inplane resonant mode from the unwanted resonant modes. The resonant modes that are close together, in terms of resonant frequency, can result in undesired movement. Undesired movement occurs when the energy from one mode is transferred to the other mode, due to a small difference in resonant frequency of the two modes. It is highly important to separate other resonant modes from the desired in the plane resonant mode.

\subsection{FEM Simulation Results of Resonance Structure}

Suggested designs in Figure 3 are simulated by FEM software for the natural frequency and resonant modes for both design approaches. Only the simulated values for Design 1 are given in Table 1a) for space saving reasons. Simulated results could be observed in detail for Design 2 in [12]. All designs are simulated with the considered spring ratios $0.8 \times 0.25,1.5 \times 0.25,1.5 \times 0.5$ and $0.8 \times 0.5$ in [mm]. The simulated modes for spring ratios $0.8 \times 0.25$ are presented in Table 1a). The resonant mode of interest or in the plane movement of the diffuser is named Mode I. Mode II is the out-of-plane movement where the diffuser is moving along y axis. Mode III is as well out of the plane movement that is characterized with the diffuser twisting around $x$ axis. Note, only the modes that can influence the proper functionality of the resonant structure are simulated.

From the simulated result in Table 1a), it could be observed that for the two designs the spring ratios show good results in terms of resonant frequency and separate the two first modes. Simulated results for Design 2 shown in [12] indicate slightly higher frequencies compared to Design 1 with the same spring structure. It can be noticed that the resonant frequencies, starting from Mode III and to Mode VI, are very high and the LSR is not meant to operate at such frequencies. Therefore, the mentioned modes do not represent a threat to the system. The drawback is the structure thickness of $1.5 \mathrm{~mm}$, which could result in higher manufacturing price and higher stiffness of the structure. With the higher stiffness and relatively high resonant frequency, compared to the $0.8 \mathrm{~mm}$ structure, it would need considerably more power to achieve resonance. 
Table 1. Resonant frequency's and modes for considered spring ratio for Design 1; a) first design b) optimized design with three spring length approaches and with the added $3 \mathrm{~mm}$ thick diffuser
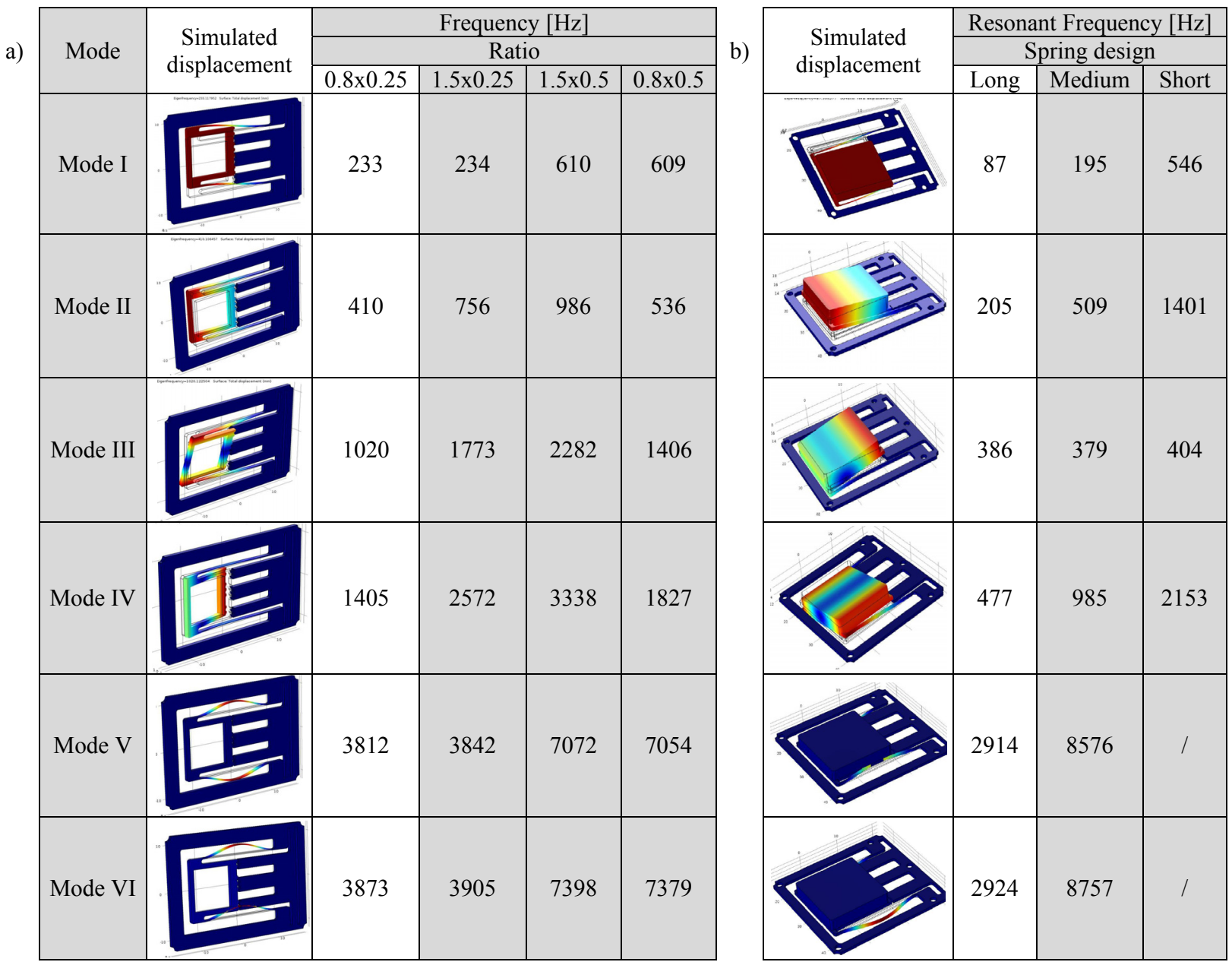

Because of the mentioned the $1.5 \mathrm{~mm}$ structure is no more considered in the design process. Design 1, performed well in resonant frequency and splitting the resonant modes for both $0.8 \times 0.25$ and $0.8 \times 0.5$ spring ratio. Due to the short spring structure, the displacement will most likely be small, the reason is higher stiffness. Taking into account the observed it could be concluded that the structure with $0.8 \mathrm{~mm}$ thickness and $0.5 \mathrm{~mm}$ thick springs, is not a good example for further evaluation due to the higher stiffness that could result in low displacement and higher power needs. This leads to the decision that only Design 1 resonant structure is taken into account for the further LSR development. Design 1 can achieve resonant frequencies up to $200 \mathrm{~Hz}$, the resonant modes are well divided (with almost $200 \mathrm{~Hz}$ difference) and there is the tendency for high displacement amplitudes.

Table 2. Suggested spring lengths and simulated results, design 1

\begin{tabular}{|c|c|c|c|c|c|c|}
\hline \multirow{2}{*}{\multicolumn{2}{|c|}{$\begin{array}{l}\text { Diffuser } \\
\text { thicknes [mm] }\end{array}$}} & \multicolumn{5}{|c|}{ Spring lengths [mm] } \\
\hline & & 3,4 & 8,4 & 13,4 & 18,4 & 23,4 \\
\hline \multirow{2}{*}{0.9} & Mode I & 3922 & 686 & 309 & 184 & 125 \\
\hline & Mode II & 811 & 390 & 249 & 177 & 133 \\
\hline 3 & Mode I & 2417 & 420 & 190 & 113 & 87 \\
\hline
\end{tabular}

If the spring length is longer, it will result in higher amplitude, lower frequency and can induce the unwanted resonant mode. For better understanding of how the spring length will influence the resonant system, an analysis is conducted. Design 1 spring configuration is analysed for spring length influence. Likewise, the $3 \mathrm{~mm}$ and $0.9 \mathrm{~mm}$ thick diffuser was added to the analysis. The simulation results are presented in Table 2 . The spring lengths are chosen from the conducted analysis, the selection is 21.6, 13.4 and $8.4 \mathrm{~mm}$, respectively long, medium and short.

Optimized design is further evaluated with the added $3 \mathrm{~mm}$ thick diffuser and three spring's lengths approach. Results of the resonant structure optimization regarding the resonant modes that occur are presented in Table IB. Based on optimized resonant structure, the parameters that influence the resonant modes are selected and the final design version is made regarding the resonant frequencies. Final design which is further developed for best performance is presented in Table 1b) as Design 1 with a long spring and $3 \mathrm{~mm}$ thick diffuser.

\subsection{Actuator Structure Design}

With the use of FE analysis more accurate results can be obtained compared to the equivalent magnetic circuit approach. Magnetic circuit analysis is a method used for simplified calculation of magnetic field problems and for magnetic force estimation [13]. The FEM is often used to verify the accuracy of the analytical method and the design procedure, as it gives a clear overview how 
design parameters, for example, actuator dimensions, influence the simulated results.

The actuator should be able to overcome the spring force and to drive the resonant structure into the resonance. The calculated spring force values are obtained through FEM software. Therefore, it is important to understand the magnetic forces in the actuator. From the geometrical aspect the magnitude of electromagnetic forces in the RA depends mostly on the air gap and the overlap of the stator and translator poles. As the overlap of the poles change the magnetic force changes. RA force components in $\mathrm{x}, \mathrm{y}$ and $\mathrm{z}$ direction have different magnitudes regarding the translator to stator position. Figure 2 shows the force component plot related to the stator to translator position.

Accordingly, two design types are suggested. The moving part (translator) is actually the diffuser carrying frame, since one edge of the frame contains the poles that interact with the stator poles. The stator is selected to be an "E" type where the coil is wound on the middle pole; the air gap is $100 \mu \mathrm{m}$. Design types are different by the number of teeth per pole. One tooth and two teeth per pole design are suggested as shown in Figure 4.

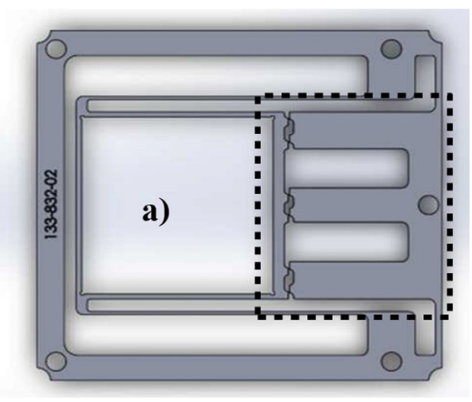

b)

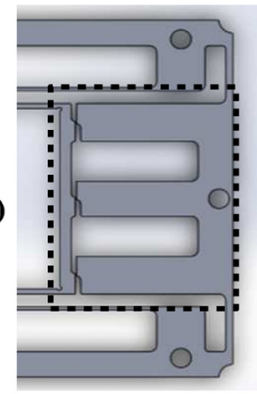

Figure 4. LSR structure with the implemented actuator. a) Double teeth; b) Single tooth actuator design

The single and double teeth version is developed regarding the maximum force and displacement that the actuator can generate. The actuator is designed already with an overlap of the teeth such as presented in Figure 5. The reason is the initial force. With the overlapped teeth the actuator will have an instantaneous force on the translator. The overlap is chosen where the propulsion force has higher value. It should be around $1 / 3$ of the tooth length, like predicted in [13]. When the coil is excited the teeth of the stator and translator will tend to align due to the generated propulsion force. The idea was to use short pulse actuation. The propulsion force is generated by exciting the coil with the previously defined frequency, and accordingly the resonant structure starts to resonate (Figure 6).

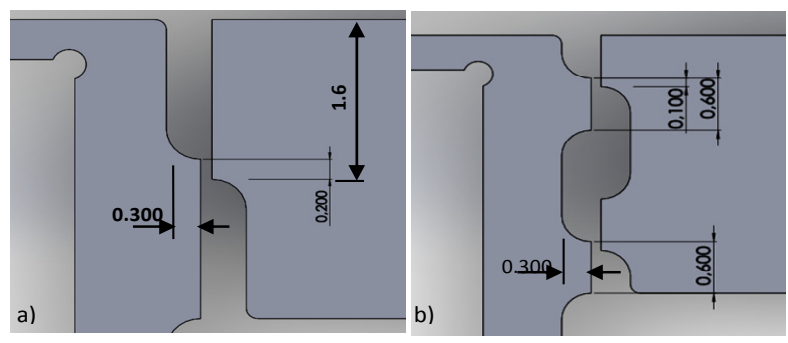

Figure 5. Actuator teeth overlap. a) Single tooth design, 200 $\mu \mathrm{m}$ overlap; b) Double teeth design, $100 \mu \mathrm{m}$ overlap

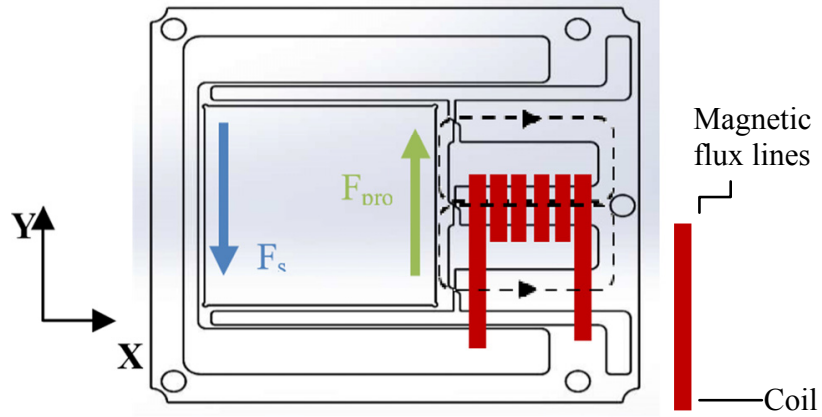

Figure 6. Resonance structure actuation (Fs - spring force, Fpro - propulsion force)

\subsection{FEM Simulation results of Actuator Structure}

Figure 7 shows a detailed surface plot of the flux density and flux lines within the structure. Saturation regions can be observed, due to the magnetic flux running through. Hence, a significant amount of magnetic flux heads towards less saturated region.

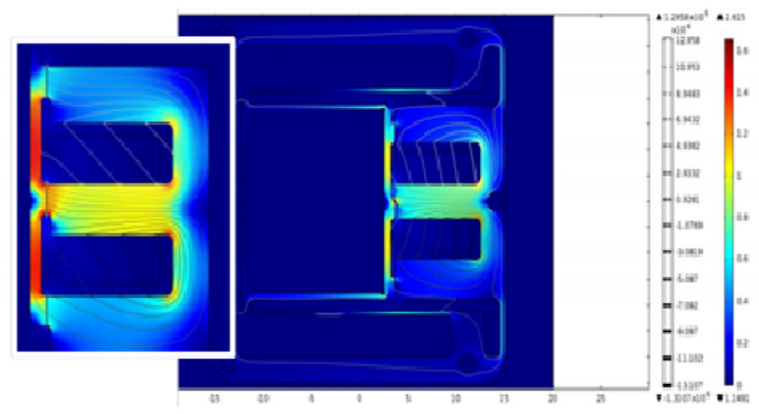

Figure 7. Magnetic flux density and magnetic flux lines within the LSR structure and close up of translator fully aligned with the stator, $1.6 \mathrm{~mm}$ overlap

From Figure 7 , the flux distribution through the entire structure is noticeable, where by the flux values at the outer stator poles are lower. The present unequal distribution of the flux in the actuating structure is resulting in lower force production. Only at the middle pole the flux distribution is respectable. The flux density having the highest value at the middle pole (close up in Figure 7), contributes to the most generated force. Absolute highest flux density (over 1.7 T) occurs in the thin domains of the moving part. This results in significant flux leakage between the stator poles causing lower force production, the leakage is represented with the flux lines in Figure 7.

The simulated results show significant saturation in the actuating structure. The saturated regions are in the translator and slightly in the stator middle pole. Higher flux density in the actuator contributes to higher generated force, however, saturated flux density results in significant flux leakage and unwanted flux distribution. Leakage is present between the stator poles and between the actuator and translator. Due to the material saturation the flux is flowing in the less saturated region, therefore the flux is distributed in the whole structure like shown in Figure 7. Mentioned lowers the overall efficiency of the actuator.

The evaluated values of generated forces and calculated spring force are given in Figure 8. The spring force is calculated for the $21.6 \mathrm{~mm}$ long spring by the same FEM software as the magnetic force. Generated force from the 
single tooth design is lower compared to the generated forces of the double teeth design. The calculated forces in Figure 8 are for the static actuation of the LSR. Regardless the dynamic actuation, the static relation between the spring force and magnetic force is important to understand the LSR operation region. The operating region is defined by the ability of the generated force to overcome the spring force for the observed translator position. The operation region is different for the two designs. The double teeth design operating region is at approximately one third of the teeth length, while the one tooth design operating region is noticeable lower.

With the dynamic actuation, the generated force from the actuator is used for a short period of time. At the start position it is desired to have a sufficient amount of force to overcome the spring force and to put the structure into resonance. Since resonance depends on the damping, the double teeth design is more suitable for dynamic actuation with a higher starting force, compared to the lower starting force generated by the single tooth design. However, processing the metal structure in mass fabrication (lasering, stamping, and etching) a simplified design with only one tooth can be a cost advantage. Regarding the efficiency, further optimization of the structure should be considered for example using only one feedback structure to increase the space for the actuation coil. Thus, higher current is not needed. The optimization should improve flux guidance and lower the leakage, contributing to the higher force development from the actuating structure.

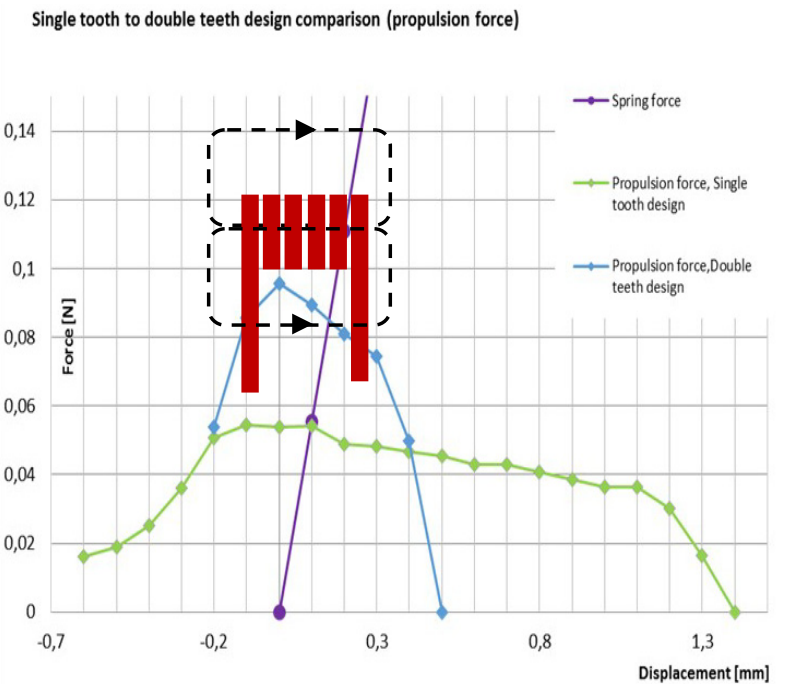

Figure 8. Force vs. translator position for LSR

\section{CONCLUSION}

This paper presents an analysis of an actuation mechanism concept for a laser speckle reducer. In this work the design concepts for an Optotune's laser speckle reducer actuator are discussed, particularly for a diffuser moving along one axis. Regarding the application field, the reluctance actuating technology was selected for actuator evaluation. The considered actuation is analysed regarding the LSR requirements, which are: low cost, low power consumption, high force, simple design, high speed, sufficient displacement, long life time. Magnetic spring steel was selected with good elastic properties, low damping and sufficient magnetic characteristic for the LSR requirements.

Resonance structure and actuating structure for one dimensional LSR was evaluated. Within the LSR evaluation two different resonant structures, with three spring lengths and two actuation structures (single tooth and double teeth) are analysed. The resonant structures are suggested regarding the maximum resonant amplitude and resonant frequency that can be achieved. To the mentioned requirements the suggested designs are simulated in FEM software. Achieved frequency range is from $87[\mathrm{~Hz}]$ to $999[\mathrm{~Hz}]$ depends on the added diffuser weight and spring structure lengthWith the conducted analysis, it was found that the resonant structures perform to the desired demands, the required speed $(>60$ $\mathrm{Hz}$ ) is achievable.

With the use of FEM software COMSOL Multiphysics, the resonate frequency and influence of geometrical parameters are determined. Magnetic flux distribution and saturation of material is observed from the analysed magnetic flux distribution the forces developed through the actuating structures are obtained. With the obtained force values the relation between the resonant structure and actuating structure is better understood. This paper, in general, gives a good overview of the LSR properties, good explanation of the working principle and a good guideline for further development.

Conducted magnetic simulation revealed that the structures show significant flux leakage and flux distribution in the entire structure, which causes lower efficiency. Regarding the leakage and distribution of flux, optimization of both structures should be considered in order to improve flux guidance and lower leakage. The results indicate good operating performance of the spring structure. In short, evaluation suggests next steps in actuating structure optimization from which better performance of the device could be obtained.

The coil for the actuator was designed to the power supply characteristics. Design approach was with the limited maximum current and voltage and the obtained coil was made to meet the LSR requirements. Since there is enough room for coil optimization, design of more efficient coil should be considered in the further development.

\section{REFERENCES}

[1] Graetzel, C., Suter, M., Aschwanden, M.: Reducing laser speckle with electroactive polymer actuators, in: Proceedings of SPIE, Vol. 9430, 943004.C) 2015 SPIE - CCC code:0277-786X/15/\$18 - doi: 10.1117/12.2086088, Smart structures/NDE, 2015.

[2] Goodman, J.W.: Speckle phenomena in optics: theory and applications, Roberts and Company Publishers, Englewood, Colorado, 2007.

[3] Giger, J., Blum, M., Aschwanden, M.: Laser Speckle Reduction based on electroactive polymers, at: The 1st Advanced Lasers and Photon Sources (ALPS'12), Yokohama, Japan, 2012.

[4] Stadler, D., Suter, M., Ventura, M., Niederer, D.: Speckle reduction with reluctance force-based oscillating diffusors, at: The 4th Laser Display and Lighting Conference (LDC'15), Yokohama, Japan, 2015. 
[5] Cigarini, F., Ito, S., Konig, J., Sinn, A., Schitter, G.: Compensation of Histeresis in Hybrid Reluctance Actuator for High Precision Motion, IFACPapersOnLine, Vol.52, Issue 15, pp.477-482, 2019.

[6] Csencsics, E., Schlarp, J., Schopf, T., Schitter, G.: Compact high performance hybrid reluctance actuated fast steering mirror, Mechatronics, Vol. 62, Article 102251, 2019.

[7] Ramirez-Laboreo, E., Sagues, C.: Reluctance actuator characterization via FEM simulations and experimental tests, Mechatronics, Vol. 56, pp. 58-66, 2018.

[8] Ganti, S.D.: Analysis of performance of singlephase reluctance linear motor, Master thesis, Louisiana State University, Baton Rouge, 2005.

[9] Suter, M.: Photopatternable superparamagnetic nanocomposite for the fabrication of microstructures, $\mathrm{PhD}$ thesis, ETH Zurich, Zurich, 2011.

[10] Ziegenbein, J.: Magnetic Clamping Structures for the Consolidation of Composite Laminates, Master thesis, Woodruff School of Mechanical Engineering, Georgia Institute of Technology, Atlanta, 2011.

[11] Vogel, O., Ulm, J.: Theory of Proportional Solenoids and Magnetic Force Calculation Using COMSOL Multiphysics, in: Excerpt from the Proceedings of the COMSOL Conference, Stuttgart, 2011.

[12]Popović, A.: Reluctance Actuator for Laser Speckle Reducer, Master Thesis (in English), Faculty of Mechanical Engineering, University of Belgrade, Belgrade, 2013.

[13] Krishnan, R.: Switched Reluctance Motor Drives; Modelling, Simulation, Analysis, Design and Appli- cations, CRC Press LLC, Boca Raton, Florida, 2001.

\section{УТИЦАЈ ПАРАМЕТАРА ПРОЈЕКТОВАҢА НА РАСПОДЕЛУ МАГНЕТНОГ ФЛУКСА КОД РЕЛУКТАНТНОГ АКТУАТОРА}

\section{А. Поповић, Б. Бојовић, М. Шутер, Д. Ниедедер}

Рад представља анализу релуктантног актуатора, који се користи за смањење неправилности приказаних слика код применом покретних дифузера ласерских пројектора, дисплеја, уређаја у метрологији и ЗД скенера. Концептуална конструкција за једнодимензионални актуациони механизам редуктора ласерских неправилности је разматрана кроз различите структуре. У питању су два типа резонујуће структуре са три различите дужине опруге и две актуационе структуре са једним или два озубљења. Детаљна процена релуктантног актуатора је извршена на основу поједностављеног конструкционог решења и функционалних захтева (генерисана сила и максимални померај) за редуктор ласерских неправилности. Коришћењем програмског пакета COMSOL Multiphysics одређени су резонантне фреквенције и геометријски параметри. Према симулираној расподели магнетног флукса у материјалу и засићењу, добијене су силе које настају у актуационој структури. Процена резултата сугерише даље кораке за оптимизацију актуационе структуре, чиме би се добиле боље перформансе уређаја. 